\title{
Familial Study on "Sinking pre-beta", the Lp(a) Lipoprotein, and its Relationship with Serum Lipids, Apolipoprotein A-I and B and Clinical Atherosclerosis
}

\author{
By A. Pagnan \\ Istituto di Medicina Clinica-Clinica Medica II, Università di Padova (Italy)
}

\section{G. Kostner}

Institute of Medical Biochemistry, University of Graz (Austria)

\section{Monica Braggion, Lorena Ziron}

Istituto di Medicina Clinica-Clinica Medica II, Università di Padova (Italy)

Gabriele Bittolo Bon and P. Avogaro

Ospedale Regionale Generale-Centro per l'Aterosclerosi, Venezia (Italy)

C.N.R. Medicina Preventiva, Unità di Venezia (Italy)

(Received May 10/October 6, 1982)

Summary: A total of 42 family members, 21 females and 21 males, distributed in 3 generations were studied; 32 were blood related while 10 were controls (not blood.related).

The familial propositus, a young male subject 36 years old, who had suffered from juvenile acute myocardial infarction, exhibited upon lipoprotein agarose gel electrophoresis two distinct pre-beta bands. The slow prebeta component turned out to be a "sinking pre-beta", the $\mathrm{LP}_{\mathrm{p}}(\mathrm{a})$ lipoprotein. The familial distribution of the character "sinking pre-beta lipoprotein", as it appeared on agarose gel electrophoresis of whole serum, and the segregation analysis data confirm an autosomal dominant transmission.

No sex differences were observed in the prevalence of the sinking pre-beta lipoprotein. Serum mean levels of total cholesterol, triglycerides, apolipoprotein A-I and B and of the very low density total cholesterol/triglycerides ratio did not discriminate between $(+)$ and $(-)$ "sinking pre-beta lipoprotein". In all the family members the $\mathrm{Lp}(\mathrm{a})$ antigen was measured by rocket immunoelectrophoresis.

Comparing the $\mathrm{Lp}$ (a) values with the behaviour of the "sinking pre-beta lipoprotein" in agarose gel electrophoresis, we demonstrated that the ability to visualize a slow moving pre-beta component, identified as the "sinking pre-beta lipoprotein", is correlated with serum $L p(a)$ levels above $0.3 \mathrm{~g} /$.

An inverse relationship between apolipoprotein $A-I$ and $L p(a)$ values was observed $(r=0.36 ; p<0.05)$. In spite of relatively low apolipoprotein A-I levels and high $L p(a)$ values, no clinical patterns of atherosclerotic diseases were found in the family members. The reasons for this discrepancy are discussed. 
Familien-Studie über ,sinking prae-beta“, das Lp(a)-Lipoprotein und seine Beziehungen zu Serumlipiden, Apolipoprotein A-I und B sowie klinisch manifester Arteriosklerose

Zusammenfassung: Aus drei Generationen wurden insgesamt 42 Familienangehörige, 21 männlich und 21 weiblich, untersucht; davon waren 32 blutsverwandt, während 10 nicht-blutsverwandte als Kontrollen dienten.

Der vorgestellte Fall, ein 36jähriger Mann, der an jugendlichem akuten Myokardinfarkt erkrankte, zeigte in der Lipoprotein-Agarosegelelektrophorese zwei deutlich unterschiedene prae- $\beta$-Banden. Die langsame prae$\beta$-Komponente erweist sich als ein „,sinking prae- $\beta$ “, das Lp(a)-Lipoprotein.

Die familiäre Verteilung des Charakteristikums „sinking prae- $\beta$ “-Lipoprotein, nachgewiesen durch Agargelelektrophorese des Gesamt-Serums, und die Daten der Aufspaltungsanalyse bestätigen eine autosomal dominante Vererbung.

In der Prävalenz des „,sinking prae- $\beta$ “-Lipoproteins wurden keine Geschlechtsunterschiede bemerkt. Die Konzentrationen von Gesamt-Cholesterin, Triglyceriden, Apolipoprotein A-I und B im Serün sowie das Verhältnis Gesamt-Cholesterin/Triglyceride in den VLDL ließen nicht zwischen „sinking prae- $\beta$ “-positiv oder -negativ unterscheiden. Bei allen Familienangehörigen wurde das Lp(a)-Antigen durch Laureli (,,rocket")-Immunelektrophorese gemessen. Durch Vergleich der L $\mathrm{p}(\mathrm{a})$-Werte mit dem Vèrhalten des ,sinking prea- $\beta$ “-Lipoproteins in der Agargelelektrophorese zeigten wir, daß das Sichtbarmachen einer langsam wandernden prae- $\beta$-Komponente, identifiziert als das ,sinking prae- $\beta$ “, an Lp(a)-Konzentrationen $>0,3 \mathrm{~g} / \mathrm{l}$ 'Serum gẹbunden ist.

Eine umgekehrte Beziehung zwischen Apolipoprotein A-I- und Lp(a)-Werten wurde beobachtet $(r=0,36$; $p \leqslant 0,05)$. Trotz relativ geringer Apolipoprotein A-I- und hoher Lp(a)-Werte wurde keine klinisch manifeste Arteriosklerose bei den Familienangehörigen gefunden. Die Ursachen für diese Diskrepanż wèrden diskutiert.

\section{Introduction}

The general interest concerning the $\mathrm{Lp}(\mathrm{a})$ lipoprotein, also called "sinking pre-beta", is mainly due to its possible relationship with the development of premature atherosclerosis $(1-6)$. Although the reported prevalence of the "sinking pre-beta", as recorded by agarose gel electrophoresis, is quite variable $(2,4,5,7)$, detectable amounts of the $\mathrm{Lp}$ (a) lipoprotein, as determined by immunological methods, are present almost in all subjects. The aim of our study was to analyse the correlation between serum $\mathrm{Lp}$ (a) levels, as measured by rocket immunoelectrophoresis, and the electrophoretic appearance of the "sinking pre-beta". Moreover, we have evaluated in a large family the familial aggregation of the "sinking pre-beta" ( $L p(a)$ lipoprotein) and its relationship with serum lipids, A-I and B apolipoproteins and finally the prevalence of clinical atherosclerosis.

\section{Materiàls and Mëthods}

The propositus of our family study is a male subject 36 years old, admitted to our clinic for an acute myocardial infarction. The diagnosis of myocardial infarction was made on the usual clinical, enzymatic and electrocardiographic criteria. Some clinical and chemical data concerning the propositus are refferred in table 1 . Besides the propositus, $\mathbf{4 1}$ family members were included in the study: 10 controls (not bloọd related) añd 31 bloọ rèătives bèlonging to 3 generations (tab. 2). Rest and exercise electrocardiograms were performed on all the blood relatives; the Minnesota Code was used for the interpretation of the electrocardiographic tracings. Blood pressure was taken in supine position by means of a Riva-Rocci instrument. Diastolic blood pressure was recorded at the disappearance of the Korotkow tones (V phase).

Agarose gel electrophoresis was performed accộrding to a modification (8) of the technique of Noble (9). Serum total cholesterol and triglycerides were measured on Autoanalyżer Technicon II according to standard enzymatic methods. The intermediate density lipoprotein fraction $(\mathrm{d}=1.006$ to $1.019 \cdot \mathrm{kg} /$ ) was obtained by ultracentrifugation according to Havel et al. (10). In order to confirm the true "sinking" nature of the slow moving pre-beta band, agarose gel electrophoresis was performed with serum as well as with the $d=1.019 \mathrm{~kg} /$ bottom fraction and the $d<1.006 \mathrm{~kg} /$

Tab. 1. Clinical and chemical data concerning the propositus (B. B.).

\begin{tabular}{|c|c|c|c|c|c|c|c|c|c|c|}
\hline $\begin{array}{l}\text { Age } \\
\text { (a) }\end{array}$ & Sex & $\begin{array}{l}\text { Blood } \\
\text { pressure } \\
(\mathrm{mmHg})\end{array}$ & $\begin{array}{l}\begin{array}{l}\text { Smoking } \\
\text { cigarettes }\end{array} \\
\text { (number) }\end{array}$ & $\begin{array}{l}\begin{array}{l}\text { Blood } \\
\text { glucose }\end{array} \\
(\mathrm{g} / \mathrm{l})\end{array}$ & $\begin{array}{l}\text { Total } \\
\text { cholesterol } \\
\text { (TC) } \\
(\mathrm{g} / \mathrm{l})\end{array}$ & $\begin{array}{l}\text { Triglycerides } \\
\text { (TG) } \\
(\mathrm{g} / \mathrm{l})\end{array}$ & $\begin{array}{l}\text { VLDL } \\
\text { TC/TG } \\
\text { ratio }\end{array}$ & $\begin{array}{l}\operatorname{Lp}(\mathrm{a}) \\
(\mathrm{g} / \mathrm{I})\end{array}$ & $\begin{array}{l}\text { Apolip } \\
\text { A-I } \\
(\mathrm{g} / \mathrm{l})\end{array}$ & $\begin{array}{l}\text { protein } \\
\text { B } \\
\text { (g/l) }\end{array}$ \\
\hline 36 & $\delta$ & $150 / 95$ & 20 & 0.95 & 3.05 & 1.84 & 0.27 & 0.77 & 1.09 & 1.57 \\
\hline
\end{tabular}


fraction (very low density lipoproteins) for all family members. Sinking pre-beta positive refers to the appearance of the slow moving pre-beta band upon agarose gel electrophoresis of whole serum. Sinking pre-beta negative refers to the absence of the slow moving pre-beta band upon agarose gel electrophoresis in the whole serum and in $d=1.019 \mathrm{~kg} / \mathrm{l}$ bottom fraction. Serum concentrations of $L p(a)$ lipoprotein, apolipoprotein A-I and B were measured by rocket immunoelectrophoresis by the Laurell technique as reported previously $(6,11,12)$.

Tab. 2. Presentation of the family members.

\begin{tabular}{lllll}
\hline Subjects & Number & $\begin{array}{l}\text { Sex } \\
\delta\end{array}$ & $\begin{array}{l}\text { Age (a) } \\
\overline{\mathbf{x}} \pm \text { SD }\end{array}$ \\
\hline $\begin{array}{l}\text { Blood } \\
\text { relatives }\end{array}$ & $14(\mathrm{I}, \mathrm{II})$ & 9 & 5 & $53.2 \pm 13.6$ \\
$\begin{array}{l}\text { Controls } \\
\text { (not blood related) }\end{array}$ & $18(\mathrm{III})$ & 9 & 9 & $15.1 \pm 4.2$ \\
All & 10 & 3 & 7 & $48.2 \pm 14.9$ \\
\hline
\end{tabular}

I, II = Ist and IInd generation

III = IIIrd generation

\section{Results}

In the propositus (B. B. age 36 ) the slow moving pre-beta component observed in the serum sank at density $1.019 \mathrm{~kg} / \mathrm{l}$ (fig. 1). In the family kindred the prevalence of the double pre-beta lipoproteinaemia was $28 \%$.

Figure 2 shows the family distribution of the character "sinking pre-beta" positive. The appearance of the character sinking pre-beta among the family members is consistent with an autosomal dominant transmission, as confirmed by segregation analysis: no "sinking pre-beta" positive children are observed when this character is absent in both of the parents.

No sex differences were observed in the prevalence of the "sinking pre-beta". The family history was negative for ischaemic heart diseases such as angina pectoris and myocardial infarction or cerebrovascular accidents. The exclusion of coronary heart disease was based on the clinical electrocardiographic and exercise test criteria. As for the other major risk factors, hypertension (blood pressure $>160 / 90$ $\mathrm{mmHg}$ ) was present in 3 family members (nos. 2, 3, 4), clinical diabetes in one (no. 5), cigarette smoking

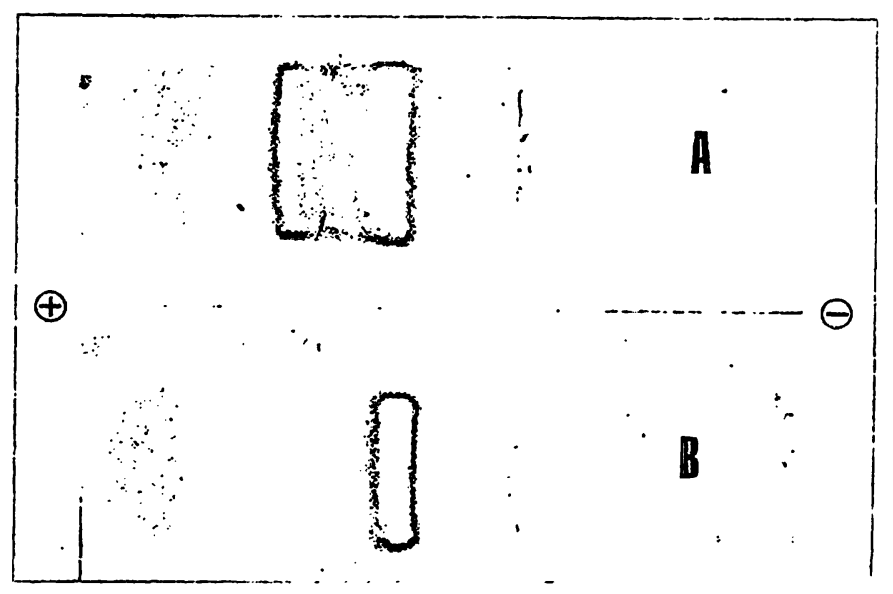

Fig. 1. (B. B. age 36): Agarose gel electrophoresis of whole serum (A) and of the $1.019 \mathrm{~kg} / \mathrm{l}$ bottom fraction (B). In $A$ two pre-beta components are clearly shown. In $B$ the "sinking pre- $\beta$ " bänd is represented.

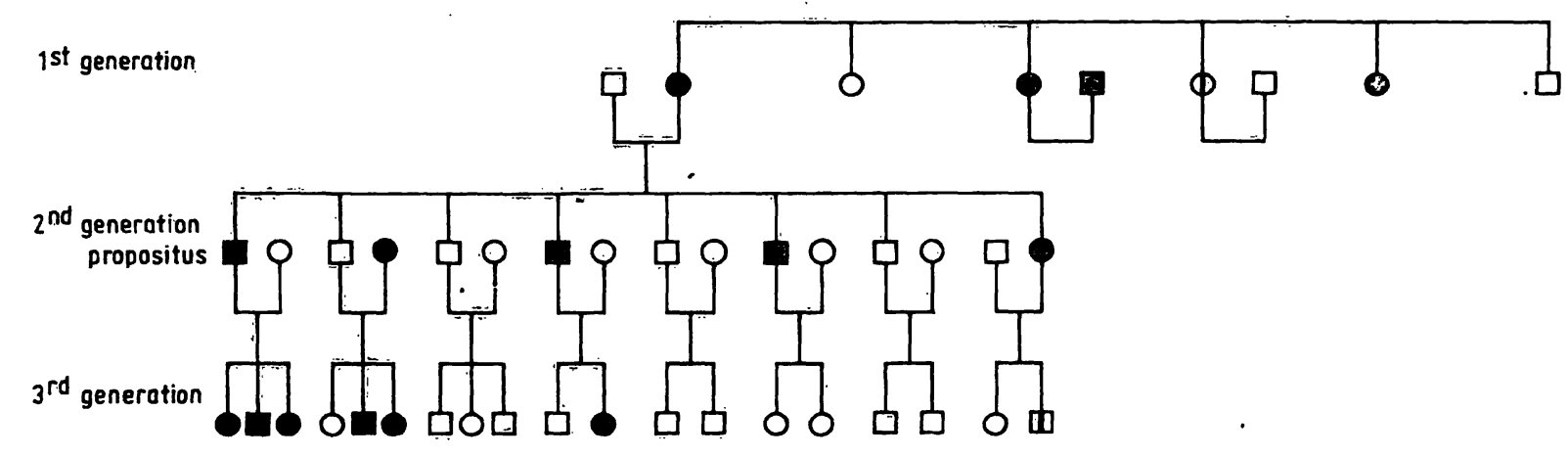

Fig. 2. Family tree subdivided into 3 generations. The mean age and the number of subjects belonging to 3 generations are as follows: 1 st generation $n 8$, age $68.4 \pm 8.0 ; 2$ nd generation $n 16$, age $42.5 \pm 6.1 ; 3$ rd generation $n 18$, age $15.2 \pm 4.2$.

(口) $\delta$

O. $\%$

11 (1) not studied

1. "sinking pre-beta" on agarose gel electrophoresis of whole serum $(L p(a)>0.3 g / 1)$ 
(>15/day) in one (no. 4), moderate hypercholesterolaemia in two (nos. 2 and 7); in no. 2 hypercholesterolaemia was associated with high $\mathrm{Lp}(\mathrm{a})$ values; all these subjects belonged to the 1 st generation (tab. 5). In fact, except for the propositus none of these relevant risk factors were present in the younger generations (IInd and IIIrd).

The "sinking pre-beta" negative subjects exhibited the lowest $\mathrm{Lp}(\mathrm{a})$ values, while the highest were observed in the "sinking pre-beta" positive: intermediate values of $L p(a)$ were recorded in the subjects showing the "sinking pre-beta" phenomenon only in the density $d=1.019 \mathrm{~kg} / \mathrm{l}$ bottom fraction (tab. 3 ). The distribution of the $\mathrm{Lp}(\mathrm{a})$ values clearly shows that no significant overlapping is observed according to the presence or absence of the "sinking pre-beta" phenomenon (tab. 3 and fig. 3 ); a $\mathrm{Lp}(\mathrm{a})$ value of $0.3 \mathrm{~g} / 1$ represents the lowest level for the electrophoretic appearance of the "sinking pre-beta".

Tab. 3. Mean $L p(a) \pm$ standard deviation (SD) in "sinking prebeta" positive and negative individuals.

\begin{tabular}{lll}
\hline "Sinking pre-beta" & Lp(a) & Range \\
& $(\mathrm{g} / \mathrm{l})$ & $(\mathrm{g} / \mathrm{l})$ \\
& $\overline{\mathrm{x}} \pm \mathrm{SD}$ & \\
&
\end{tabular}

\begin{tabular}{|c|c|c|}
\hline $\begin{array}{l}\text { Positive in serum (n 16) } \\
\text { Negative in } d=1.019 \mathrm{~kg} / 1 \\
\text { bottom }(\mathrm{n} 6)\end{array}$ & $\begin{array}{l}0.70 \pm 0.20^{*} \\
0.32 \pm 0.11\end{array}$ & $0.36-1.21$ \\
\hline Negative (n 20) & $0.12 \pm 0.08$ & $0.02-0.30$ \\
\hline
\end{tabular}

* Significantly different from each other $(p<0.01)$.

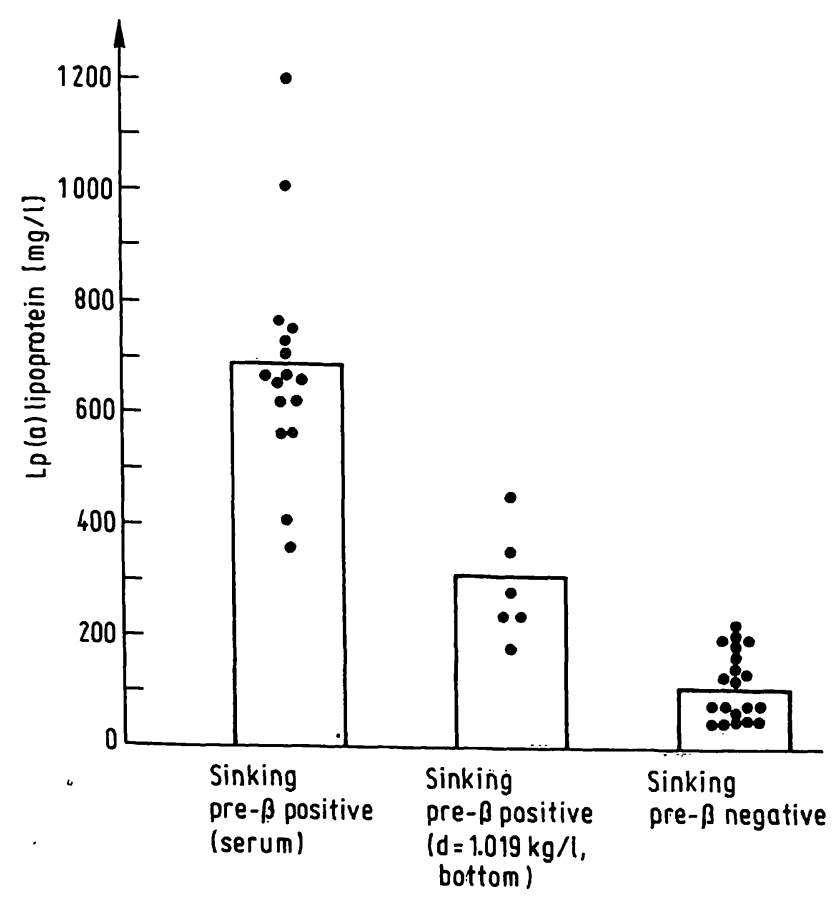

Fig. 3. $\mathrm{Lp}(\mathrm{a})$ values in "sinking pre-beta" positive and "sinking pre-beta" negative individuals.
Serum levels of total cholesterol, very low density lipoprotein (VLDL) total cholesterol/triglycerides ratio and apolipoprotein A-I and B did not significantly differ between "sinking pre-beta" positive and "sinking pre-beta" negative subjects, while mean serum triglycerides were significantly higher in the former group (tab. 4).

Tab. 4. Comparison of mean $\pm S D$ serum total cholesterol, triglycerides, their very low density lipoprotein ratio; apolipoprotein $\mathrm{A}-\overline{\mathrm{I}}, \overrightarrow{\mathrm{B}}$, and age between "sinking pre-beta" positive and negative individuals.

\begin{tabular}{|c|c|c|c|}
\hline & $\begin{array}{l}\text { "Sinking pre-be } \\
\text { positive } \\
(n=16)\end{array}$ & $\begin{array}{l}\text { a" } \\
\text { negative } \\
(n=20)\end{array}$ & $\mathrm{p}$ \\
\hline $\begin{array}{l}\text { Age (a) } \\
\text { Total cholesterol } \\
(\mathrm{g} / \mathrm{l})\end{array}$ & $\begin{array}{l}40.1 \pm 22.6 \\
2.16 \pm 0.48\end{array}$ & $\begin{array}{l}32.9 \pm 21.0 \\
2.10 \pm 0.50\end{array}$ & $\begin{array}{l}\text { n.s. } \\
\text { n.s. }\end{array}$ \\
\hline $\begin{array}{l}\text { Triglycerides (g/l) } \\
\text { VLDL TC/TG } \\
\text { Apolipoprotein } \\
\text { A-I (g/l) }\end{array}$ & $\begin{array}{l}1.03 \pm 0.65 \\
0.25 \pm 0.12 \\
1.07 \pm 0.22\end{array}$ & $\begin{array}{l}0.63 \pm 0.32 \\
0.29 \pm 0.01 \\
1.22 \pm 0.22\end{array}$ & $\begin{array}{l}p<0.05 \\
\text { n.s. }\end{array}$ \\
\hline $\begin{array}{l}\text { Apolipoprotein B } \\
\text { (g/l) } \\
\text { Apo B/Apo A-I }\end{array}$ & $\begin{array}{l}0.86 \pm 0.34 \\
0.86 \pm 0.48\end{array}$ & $\begin{array}{l}0.73 \pm 0.34 \\
0.61 \pm 0.32\end{array}$ & $\begin{array}{l}\text { n.s. } \\
\text { n.s. }\end{array}$ \\
\hline
\end{tabular}

A significant correlation was found between serum total cholesterol and $L p(a)$ values in "sinking prebeta" positive subjects ( $16 ; r=0.50 p<0.05$ ), but not in the "sinking pre-beta" negative ones (n 20; $\mathrm{r}=0.10 \mathrm{p}$ n. s.).

Apolipoprotein A-I was inversely correlated with $\mathrm{Lp}(\mathrm{a})(\mathrm{n} 42 ; \mathrm{r}=0.36 \mathrm{p}<0.05)$. This correlation was consistently higher ( $\mathrm{n} 32 ; \mathrm{r}=0.60 \mathrm{p}<0.01$ ) when the oldest subjects, belonging to the 1 st generation were excluded. After this exclusion, mean apolipoprotein A-1 levels were significantly lower in the "sinking pre-beta" positives as compared to the "sinking pre-beta" negatives (apoprotein A-I: $1.08 \pm 0.11 \mathrm{~g} / \mathrm{l}$ against $1.22 \pm 0.22 \mathrm{~g} / \mathrm{p} \mathrm{p}<0.05)$.

No significant correlation was found for the following parameters: $\mathrm{Lp}(\mathrm{a})$ vs triglycerides $(\mathrm{r}=0.09)$, triglycerides vs apolipoprotein A-I $(r=0.20)$. Ľp(a) did not correlate with apolipoprotein $B$ in the total collective of subjects $(\mathrm{r}=0.14)$, or in the "sinking pre-beta" positive subjects alone $(r=0.30)$.

\section{Discussion}

In previous papers it was stressed that the presence of an atypical slow moving pre-beta component upon lipoprotein agarose gel electrophoresis of serum 
does not invariably refer to the presence of $L p(a)$, being often related to a very low density lipoprotein population, the so called "Double floating pre-beta very low density lipoprotein" or "Late pre-beta" (13-14).

Comparing the $\mathrm{Lp}(\mathrm{a})$ values with the behaviour of the "sinking pre-beta" in agarose gel electrophoresis, we demonstrated that the ability to visualize a slow moving pre-beta component, identified as the "sinking pre-beta", is correlated with serum $\mathrm{Lp}(\mathrm{a})$ levels above $0.3 \mathrm{~g} /$.

The familial transmission of the "sinking pre-beta" ascertained previously through an autosomal dominant trait $(1,4,15)$ is confirmed in the present study.

Concerning the relationship between $L p(a)$ and serum lipids (total cholesterol and triglycerides), no significant difference between "sinking pre-beta" positive and negative subjects was found, thus confirming previous data $(4,5)$. However a significant correlation was found between serum total cholesterol and $\mathrm{Lp}(\mathrm{a})$ in "sinking pre-beta" positive, but not in "sinking pre-beta" negative subjects.

This correlation was higher when the oldest subjects, belonging to the 1 st generation were excluded. The exclusion of the oldest subjects. is pertinent if we consider that serum $\mathrm{Lp}(\mathrm{a})$ concentrations are age related (16). The positive correlation observed between serum total cholesterol and $\mathrm{Lp}(\mathrm{a})$ lipoprotein in "sinking pre-beta" positive subjects suggests that $\mathrm{Lp}$ (a) lipoprotein gives a consistent contribution to total serum cholesterol only when its serum levels are abnormally high, resulting in the electrophoretic appearance of the "sinking pre-beta" band. The inverse relationship observed between apolipoprotein A-I and $L p(a)$ is interesting in the light of several studies $(1-6,17-19)$, which report an increased prevalence of atherosclerotic complications in subjects having abnormally high levels of serum $L p(a)$ (and/or "sinking pre-beta" positive), and of studies showing lower levels of apolipoprotein A-I or high density lipoproteins-cholesterol in patients affected by atherosclerosis as compared to normal subjects $(11,20-23)$. Since $L p(a)$ is thought to be an independent positive risk factor for atherosclerosis (6) and apolipoprotein $A-I$ a negative one $(11,24)$, the inverse correlation observed in our study needs further investigation.

As for the clinical pattern of atherosclerosis in this family, it is surprising that, in spite of relatively low apolipoprotein A-I and high $\mathrm{Lp}(\mathrm{a})$ levels, no other significant cases of atherosclerotic diseases were found, except for the propositus.

This discrepancy may be partly explained as follows

1) the majority of our familial members are young (second and third generation); it will therefore be interesting to follow-up these young "sinking pre-beta" positive subjects in order to evaluate the incidence of new clinical atherosclerotic events;

2) the absence of significant cardiovascular events in the oldest family members (1st generation), despite the presence of the "sinking pre-beta" in five and relatively low levels of apolipoprotein A-I in four subjects, might be due to the low levels of apolipoprotein B which characterizes all the subjects, except for no. 7; other risk factors such as hypertension, smoking cigarettes, diabetes and dyslipidaemia are scarce (tab. 5).

This finding confirms our view (11) that apolipoprotein $B$ is the most effective parameter in discriminating between atherosclerotic subjects and controls. In other words, low levels of apolipoprotein A-I and of $\mathrm{Lp}(\mathrm{a})$, may be irrelevant if the levels of apolipoprotein $B$ are lower than normal.

Finally the occurrence in the propositus of a juvenile myocardial infarction was justified by the presence of other risk factors such as moderate hypertension, cigarette smoking and relatively high serum apolipoprotein B levels.

Tab. 5. Clinical and chemical data concerning the oldest subjects.

\begin{tabular}{|c|c|c|c|c|c|c|c|c|c|c|c|c|}
\hline \multicolumn{2}{|c|}{ No. Name } & \multirow{2}{*}{$\begin{array}{l}\begin{array}{l}\text { Age } \\
(\mathrm{a})\end{array} \\
79\end{array}$} & \multirow{2}{*}{$\frac{\operatorname{Sex}}{8}$} & \multirow{2}{*}{$\begin{array}{l}\begin{array}{l}\text { Blood } \\
\text { pressurë } \\
\text { (mmHg) }\end{array} \\
140 / 80\end{array}$} & \multirow{2}{*}{$\begin{array}{l}\text { Smoking } \\
\text { (cigarettes) } \\
-\end{array}$} & \multirow{2}{*}{$\begin{array}{l}\begin{array}{l}\text { Blood } \\
\text { glucose } \\
(\mathrm{g} / \mathrm{l})\end{array} \\
0.97\end{array}$} & \multirow{2}{*}{$\begin{array}{l}\text { Total } \\
\text { cholesterol } \\
(\mathrm{g} / \mathrm{l})\end{array}$} & \multirow{2}{*}{$\begin{array}{l}\text { Triglycerides } \\
\text { (TG) } \\
(\mathrm{g} / \mathrm{l})\end{array}$} & \multirow{2}{*}{$\begin{array}{l}\text { VLDL } \\
\text { TC/TG } \\
\text { ratio }\end{array}$} & \multirow{2}{*}{$\begin{array}{l}\mathrm{Lp}(\mathrm{a}) \\
(\mathrm{g} / \mathrm{l}) \\
0.02\end{array}$} & \multicolumn{2}{|c|}{\begin{tabular}{ll}
\multicolumn{2}{l}{ Apolipoprotein } \\
A-I & B \\
$(g / l)$ & $(g / l)$
\end{tabular}} \\
\hline 1 & B. T. & & & & & & & & & & 0.99 & 0.59 \\
\hline 2 & B. C. & 73 & 9 & $190 / 120$ & - & 1.02 & 3.02 & 1.78 & 0.23 & 0.77 & 1.00 & 1.06 \\
\hline 3 & B. A. & 67 & q & $170 / 80$ & - & $0: 97$ & 2.48 & 0.84 & 0.25 & 1.21 & 1.50 & 1.08 \\
\hline 4 & B. G. & 62 & ๘ & $160 / 100$ & $10-15$ & 1.14 & 2.24 & 0.90 & 0.22 & 0.73 & 1.46 & 1.00 \\
\hline 5 & B. V. & 65 & $q$ & $150 / 85$ & - & 2.24 & 2.70 & 0.81 & 0.20 & 1.01 & 1.44 & 0.82 \\
\hline 6 & M. P. & 72 & $\delta$ & $150 / 80$ & - & 0.93 & 2.21 & 0.71 & 0.17 & 0.68 & 0.71 & 1.33 \\
\hline 7 & B. M. & 54 & q & $150 / 85$ & - & 1.04 & 3.35 & 1.13 & 0.25 & 0.11 & 1.29 & 1.60 \\
\hline 8 & C. B. & 75 & $\delta$ & $150 / 80$ & - & 1.01 & 1.76 & 0.60 & 0.16 & 0.15 & 0.79 & 0.98 \\
\hline
\end{tabular}




\section{References}

1. Pagnan, A., Donadon, W. \& Tonolli, E. (1974) Min. Med. $65,3123-3126$.

2. Avogaro, P. \& Cazzolato, G. (1975) Clin. Chim. Acta 61, 239-246.

3. Dahlen, G. (1975) Acta Med. Scand. Suppl. 570, 3-43.

4. Postle, A. D., Darmady, J. M. \& Siggers, D. C. (1978) Clin. Genet. 13, 233-236.

5. Berg, K., Dahlen, G. \& Borresen, M. L. (1979) Clin. Genet. 16, 347-352.

6. Kostner, G. M., Avogaro, P., Cazzolato, C., Marth, E., Bittolo Bon G. \& Quinci, G.B. (1981) Atherosclerosis 38, $51-61$.

7. Vogelberg, V. K., Utermann, G. \& Gries, F. A. (1973) Z. Klin. Chem. Klin. Biochem. 11, 291-296.

8. Pagnan, A., Fellin, R. \& Crepaldi, G. (1977) Acta Med. Patav. $31,71-81$.

9. Noble, R. P. (1968) J. Lipid. Res. 9, 693-700.

10. Havel, R. J., Eder, A. A. \& Bragdon, J. H. (1955) J. Clin. Invest. 34, 1343-1353.

11. Avogaro, P., Cazzolato, G., Bittolo Bon G. \& Quinci, B. (1979) Lancet II, 901-903.

12. Kostner, G. M., Avogaro, P., Bittolo Bon G., Cazżolato, G. \& Quinci, G. B. (1979) Clin. Chem. 25, 939-942.

13. Carlson, L. A. \& Ericsson, M. (1975) Atherosclerosis 21, 417-433.

14. Pagnan, A., Havel, R. J., Kane, J: P. \& Kotite, L. (1977) J. Lipid. Res. 18, 618-622.

15. Rider, A. K., Levy, R. I. \& Fredrïckson, D. S. (1970) Circulation 42, Suppl. III ${ }^{\circ}$ p. 10.

16. Pagnan, A., Kostner, G., Braggion, M. \& Ziron, L. (1982) Gerontology 28, 381 =385.

17. Dahlen, G., Ericsson, C. \& Ersson, N.'O. (1973) Opusc. Med. 5, 216-219.

18. Berg, K., Dahlen, G. \& Frick, M. H. (1974) Clin. Genet. 6, $230-235$.

19. Waltoni, K.W., Hitchenens, J, Magnani, R.N. \& Khạ, M. (1974) Atherosclerosis 20, 323-346.

20. Bradby, G. U.H., Valentê, A. J. \& Wạlton; K. W. (1978) Lancet $I, 1271=1274$.

21. Miller, N. E., Thiele, D.D., Farde, D.H. \& Mjos, O:D. (1977) Lancet $I, 965=968$.

22. Taggart, H. \& Stout, R.W. (1979) Eur. J. Clin. Invest. 9, 219-221.

23. Zilcher, H., Kaliman, J. \& Muller, M. (1979) Lancet I, 558559.

24. Alberis, J. J., Wahil, P. W.; Cabana, G. V., Hazzzard, W. R. \& Hoover, J. J. (1976) Metabolism 25, 633-639.

Prof. Antonio Pagnan

Istituto di Medicina Clinica Clinica Medica II Università di Padova

Via Giustiniani 2

I-35100 Padova 
ahnbrechend ämoglobin $A_{1 c} \ldots$

- und nur stabiles $\mathrm{HbA}_{1 \mathrm{c}}$

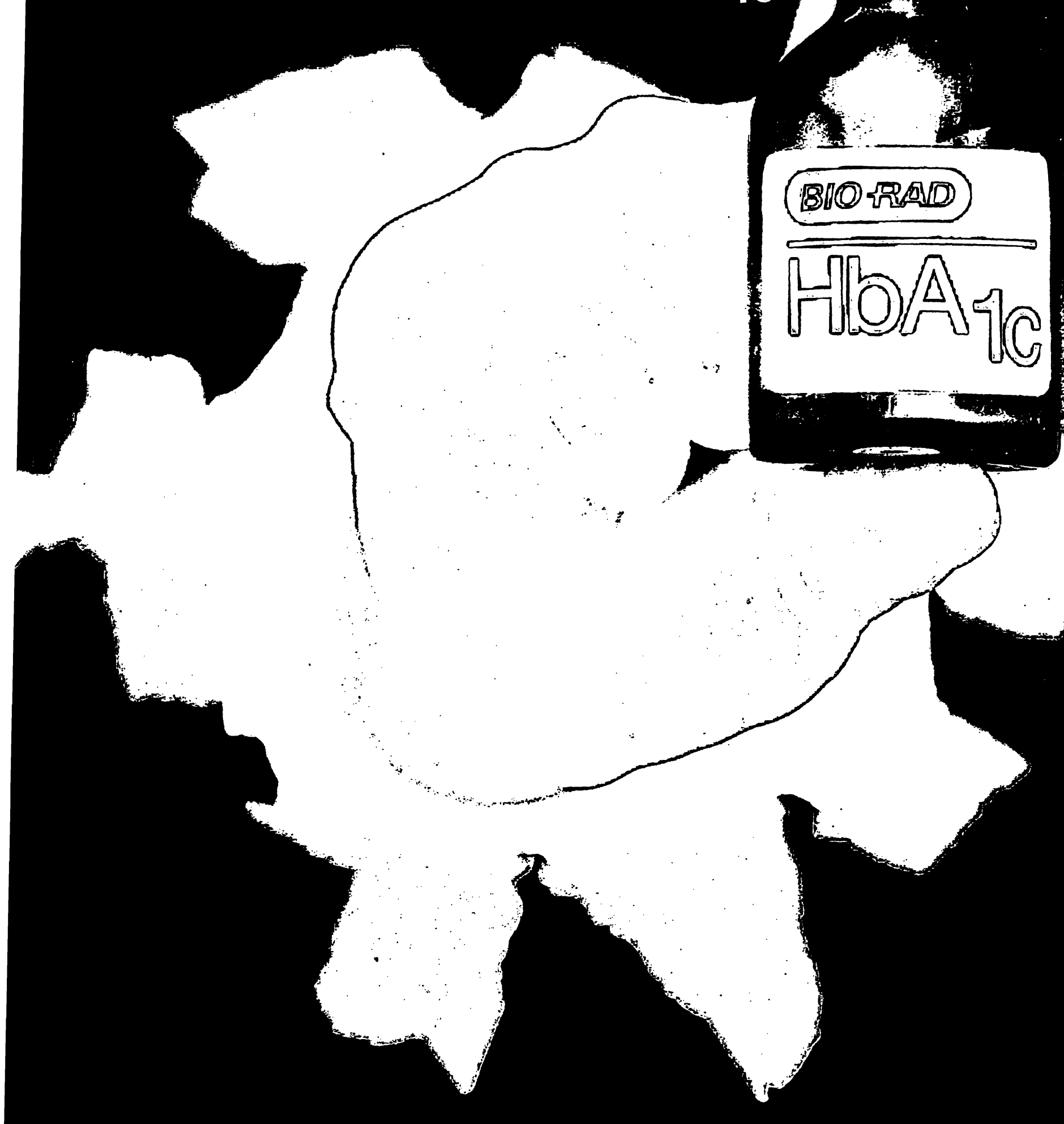

\section{BIORAD}




\section{Der Test auf den Sie gewartet haben - Nurr von BIO-RAD}

\section{Märmoglobin $\mathrm{A}_{1 \mathrm{c}}$-Säulentest}

\section{O Spezifisch Isolierung der klinisch signifikanten $\mathbf{H b A}_{1 c}-$ Unterfraktion \\ O Genau Eliminierung der labilen Schiff'schen Base \\ O Einfach \\ O Schnell 3 Kalibratoren zur Temperaturkörrektur Einfache Testausführung}

Hämoglobin $A_{1 c}\left(H_{b A_{1 c}}\right)$ - die spezifische Unterfraktion

Hämoglobin $A_{i c}$ ist schon lange als die GlykohämoglobinUnterfraktion anerkannt, welche die größte klinische Bedeutung in der Erkennung und Überwachung des Diabetes mellitus besitzt. ") Jedoch sind die gegenwärtigen Methoden zur Abtrennung des $\mathrm{HbA}_{1 \mathrm{c}}$ von $\mathrm{HbA}_{1 \mathrm{a}}$ und $\mathrm{HbA}_{\mathrm{Ib}}$ sehr zeitaufwendig und teuer.

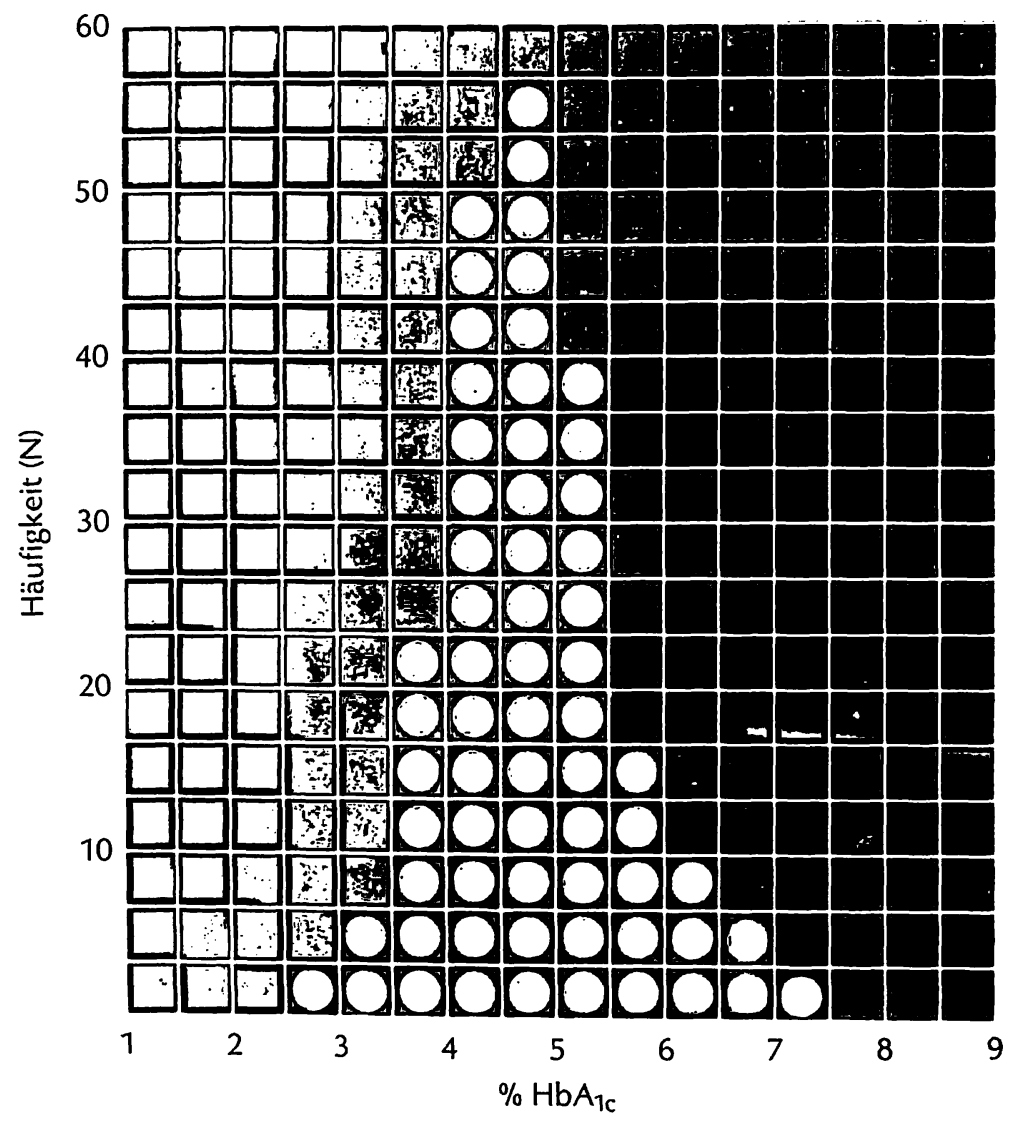

Abb. 1 Hämoglobin $A_{1 c}$-Normalwert-Verteilung. ${ }^{2)}$

Es wurden 220 nicht-diabetische Frauen und Männer untersucht. Der Mittelwert der $\mathrm{HbA}_{7 \mathrm{c}}$-Werte lag bei 4,77\%, mit einem Bereich von $2,9 \%-7,1 \%$ und einer Standardabweichung von $0,67 \%$. Der $95 \%$ Vertrauensbereich beträgt $3,43 \%-6,11 \%$.
Daher wurde die Bestimmung des Gesamt- $\mathrm{Hb}_{1}$ in der Diabetes-Diagnostik akzeptiert, trotz der Tatsachè, dàß die $\mathrm{HbA}_{1 \mathrm{a}}$ und $\mathrm{HbA}_{\mathrm{tb}}$-Unterfräktionen zu fálṣch erhöhten Werten beitragen können. ${ }^{3)}$

Dazu kommt, daß siç bei der Reäktion von Hämoglobin mit Glụkose zunäçhst eine lábile Schiff'sche Base billdet, welche zusammen mit $\mathrm{HbA}_{1 c}$ eluiert wird und die Wahrscheinlichkeit ungenauer Werte erhöht. ${ }^{4}$

Der im Blut von nicht-diabetischen Alkoholikern vor= kommende Acetaldehyd, die Carbamylierung von Hämoglobin bei urämischen Patienten, sowie ein hoher Lipidgehalt im Blut stillender Frauen, erhöhen ebenfalls die Wahrscheinlichkeit ungenauer Gesamt-HbA $-\mathrm{A}_{1}$ Werte. ${ }^{5,6,7)}$

Der BIO-RAD Hämoglobin $A_{1 c}$-Säulentest Der BIO-RAD Hämoglobin $A_{1 c}$-Säulentest ermöglicht die Bestimmung der spezifischen $\mathrm{HbA}_{1 c}$-Fraktion (Abb. 2). Mehr noch, ohne Dialyse oder spezielle Inkubation wird bei diesem $\mathrm{HbA}_{1 \mathrm{c}}$-Test die labile Schiff'sche Base - oder pre- $\mathrm{HbA}_{1 \mathrm{c}}$ - eliminiert, welche die $\mathrm{HbA}_{1}-$ Werte fälschlicherweise um 3\% oder mehr erhöhen kann. Lipämische Proben stören den Test nicht (Abb. 3, 4,5).

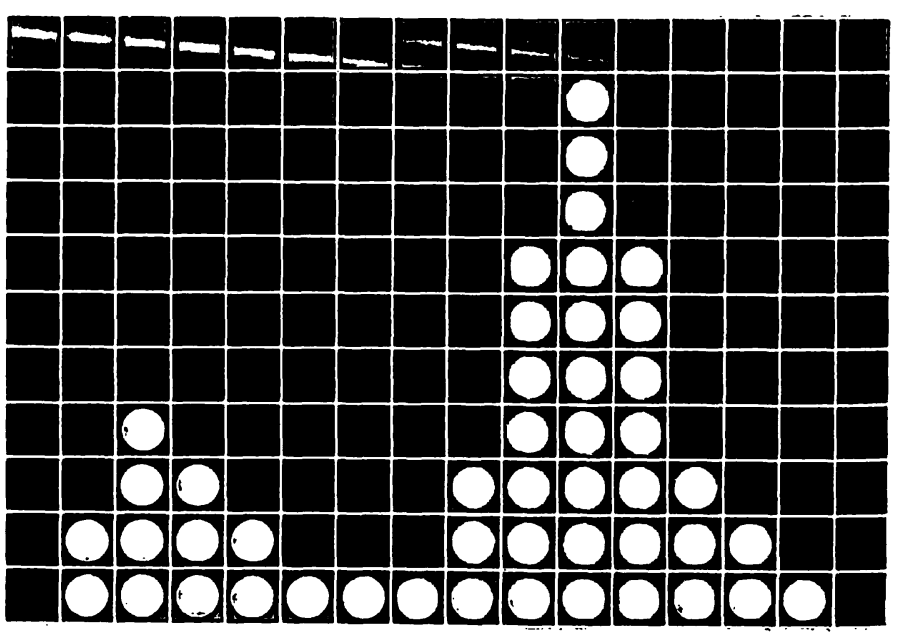

Abb. 2 Hämoglobin-Elutionsprofil einè Diabètikèrŝ. Testausführung bei $24^{\circ} \mathrm{C}$.

$2 \mathrm{HbA}_{1 \mathrm{a} T \mathrm{~b}}$

$\mathrm{HbA}_{1 \mathrm{c}}$ 


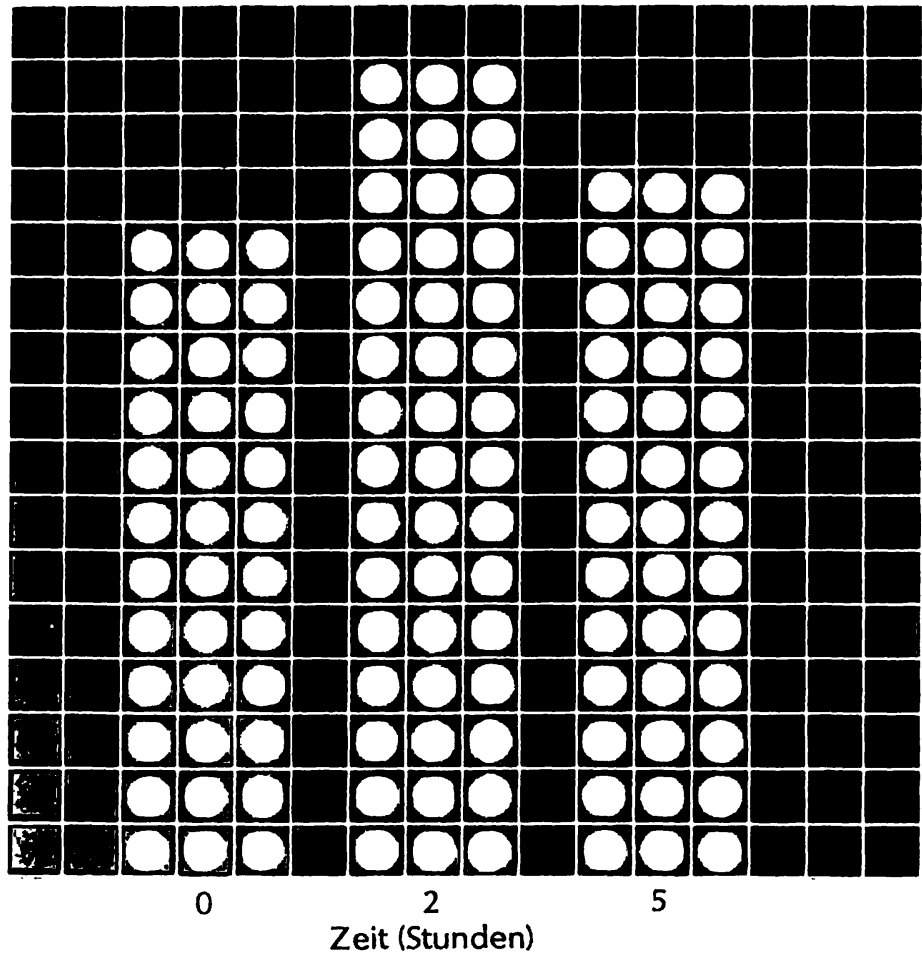

Schiff'sche Base, gemessen vor, 2 Stunden und 5 Stunden nach einem Standard-Frühstück.

Stabiles Hämoglobin $A_{1 c}$

3 Eliminierung der labilen Schiff'schen Base.

nisse einer Studie an Diabetikern. Der Anteil der labilen schen Base ändert sich mit den akuten Blutzuckerinkungen kurz vor der Probennahme. Die Eliminierung der n Schiff'schen Base ist erforderlich, um die Langzeitwirkung Monate) einer strengen Kohlenhydrat-Kontrolle richtig 2rzugeben. ${ }^{8)}$

\begin{tabular}{|c|c|c|}
\hline tientenprobe & $\begin{array}{c}" \text { "HbA } A_{i} \\
\text { Methode A) }\end{array}$ & $\begin{array}{c}\text { \% } H b A_{11} \\
\text { (Nethode B) }\end{array}$ \\
\hline ;0 mg/dl & 11,41 & 5,15 \\
\hline $0 \mathrm{mg} / \mathrm{dl}$ & 12,19 & 5,19 \\
\hline $100 \mathrm{mg} / \mathrm{dl}$ & 12,99 & 5,08 \\
\hline ontrolle & 10,83 & 5,23 \\
\hline
\end{tabular}

4 Éffizienż der Eliminieruñg der Schiff'schen Base beịm RAD Hämoglobin $\mathbf{A}_{1}$-Test.

Patientenprobe wurde angereichert mit Glukose (linke Spalte); unterschiedliche Konzentrationen zu erzielen; mitgeführt wurde ifalls eine Kontrolle, welcher keine Glucose zugesètzt wurde. I Bildung der labilen Schiff'schen Base wurden die Proben sowohl

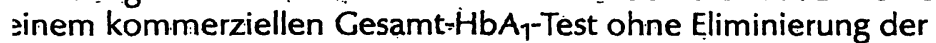
en Schiff'schen Base (A), als auch mit dem BIO-RAD-HbA $A_{1 c}$-Test (B) ysiert.

\begin{tabular}{l|l}
$\begin{array}{l}\text { (A } A_{1 c} \text {-Test (Bio-Rad) } \\
\left.\text { Hämoglobin } A_{1 c}\right)\end{array}$ & $\begin{array}{l}\mathrm{HbA}_{1} \text {-Test (kommerziell) } \\
\left(\% \text { Hämoglobin } A_{1}\right)\end{array}$ \\
\hline cht gewasch. Probe A 9,11 & Nicht gewasch. Probe B 23,29 \\
\hline :waschene Probe A 9,80 & Gewaschene Probe B 13,61 \\
\hline
\end{tabular}

1. 5 Interferenz durch erhöhte Lipidkonzentrationen.

se Tabelle zeigt die Fähigkeit des BIO-RAD Hämoglobin $A_{1 c}$-Tests, vergleich zu einer kommerziellen Methode zur Bestimmung des iamt-HbA, sogar die größtmögliche Störung durch erhöhte dkonzentrationen zu eliminieren.
Spezifität und Richtigkeit

Schnell und einfach

1. Um die roten Blutzellen zu hämolysieren, wird Vollblut mit Hämolysereagenz gemischt. Die Eliminierung der labilen Schiff'schen Base wird beim Hämolyseschritt bereits durch die Bindung der Glukose an Borat eingeleitet.

2. Die Probenhämolysate werden auf die Säulen gegeben und anschließend durch Zugabe des ersten Elutions/ Entwicklungs-Reagenz $\mathrm{HbA}_{1 \mathrm{a}}+\mathrm{HbA}_{1 b}$ von $\mathrm{HbA}_{1 \mathrm{c}}$ getrennt. Gleichzeitig wird noch vorhandene Schiff'sche Base quantitativ eliminiert.

3. Mit dem zweiten Elutions/Entwicklungs-Reagenz wird das $\mathrm{HbA}_{1 c}$ eluiert. Die quantitative Bestimmung erfolgt am Spektralphotometer bei $415 \mathrm{~nm}$ (Filterphotometer 405 mm).

\section{Drei Kalibratoren mit unterschiedlichem Gehalt an $\mathrm{HbA}_{1 \mathrm{c}}$ sichern jederzeit genaue Werte.}

Eine weitere BIO-RAD Exklusivität. In jedem Hämoglobin $A_{1 c}-K i t$ sind Kalibratoren mit unterschiedlichem Gehalt an $\mathrm{HbA}_{1 \mathrm{c}}$ inbegriffen, womit Temperaturunterschiede von $20^{\circ} \mathrm{C}-28^{\circ} \mathrm{C}$ korrigiert werden.

Durch Auftragen der gemessenen Kalibratorwerte gegen die $24^{\circ} \mathrm{C}$-Sollwerte ergibt sich eine Standardkurve, aus der die korrigierten $24^{\circ} \mathrm{C}$-Probenwerte abgelesen werden.

Wird der Test bei $24^{\circ} \mathrm{C}$ ausgeführt, können die Kalibratoren als Kontrollen verwendet werden, ụm Richtigkeit und Präzision des Tests zu ermitteln.

\begin{tabular}{|lcc|}
\hline & $\begin{array}{c}\text { Mittelwert } \\
\% \mathrm{HbA}_{1 \mathrm{c}}\end{array}$ & $\begin{array}{c}\% \mathrm{HbA}_{\mathrm{ic}} \\
\text { auf } 24^{\circ} \mathrm{C} \text { korri- } \\
\text { gierter Wert }\end{array}$ \\
\hline Test-Temp. $20^{\circ} \mathrm{C}$ & & \\
\hline Stoffwechselgesunder & 4,70 & 5,50 \\
\hline Diabetiker & 7,87 & 9,50 \\
\hline Test-Temp. $28^{\circ} \mathrm{C}$ & & \\
\hline Stoffwechselgesunder & 6,29 & 5,40 \\
\hline Diabetiker & 10,09 & 8,99 \\
\hline
\end{tabular}

Abb. 6 Richtigkeit der Hämoglobin $A_{1 c}$-Temperaturkorrektur Der bei der optimalen Testtemperatur von $24^{\circ} \mathrm{C}$ ermittelte Prozentsatz an $\mathrm{HbA}_{1 c}$ in der nicht-diabetischen Patientenprobe war $5,6 \%$ und beim Diabetiker $9,43 \%$.

Literatur

1) Koenig, R.J., Araujo, D.C. and Cerami, A., Diabetes, 25, 1 (1976).

2) Data on file at Bio Rad Laboratories.

3) Coldstein, D.E., Parker, K.M., England, J.D., et al., Diabetes, 31,70 (1982).

4) Jovanovic, $B$. , and Peterson, C.M., LAB 78, 11, July/August (1978).

5) Stevens, V.J., Fantl, W.J., Newman, C.B., et al., J. Clin Invest., 11, 361 (1981).

6) Dix, et al., Clin. Chem., 25, 3, 494 (1979)

7) Pluckiger, R., Harmon, W., Meier W., et al., New England Journal of Medicine, 304, 823-27 (1981).

8) Coldstein, D.E., Peth, S.B., England, J.D., Hess R.U., and DaCosta, I., Diabetes, 29, $623(1980)$ 


\section{Hämoglobin $A_{1 c}$-Säulentest}

Testkomponenten für 100 Bestimmungen (Best.Nr. 191-9001)

Hämolyse-Reagenz Ein Fläschchen mit $60 \mathrm{ml}$ Polyoxyethylenäther/Boratpulfer $(0,33 \% \mathrm{~V} / \mathrm{V})$.

Elutions/Entwicklungs- Elutionspuffer I. Eine Flasche mit $500 \mathrm{ml}$ Reagenz Elutions/Entwicklungs-Reagenz

(Borat/Phosphatpuffer $\mathrm{pH} \mathrm{6,7} \mathrm{und} \mathrm{Konser-}$ vierungsmittel).

Elutionspuffer II. Drei Flaschen mit je $750 \mathrm{ml}$ Elutions/Entwicklungs-Reagenz (Phosphatpuffer pH 6,7 und Konservierungsmittel).

4

Garzsäulen 100 Stück Kationenaustauscher-

ing Chromatographiesäulen.

\begin{tabular}{|c|c|}
\hline $\begin{array}{l}\text { HbA Ackalibratoren } \\
\text { Lexelinulil }\end{array}$ & $\begin{array}{l}3 \text { Fläschchen mit lyophilisiertem Human- } \\
\text { Vollbluthämolysat und Konservierungs- } \\
\text { mitteln. }\end{array}$ \\
\hline
\end{tabular}

\section{Teflon:beschichtete} Kappets

3 Teflon-beschichtete Kappen.
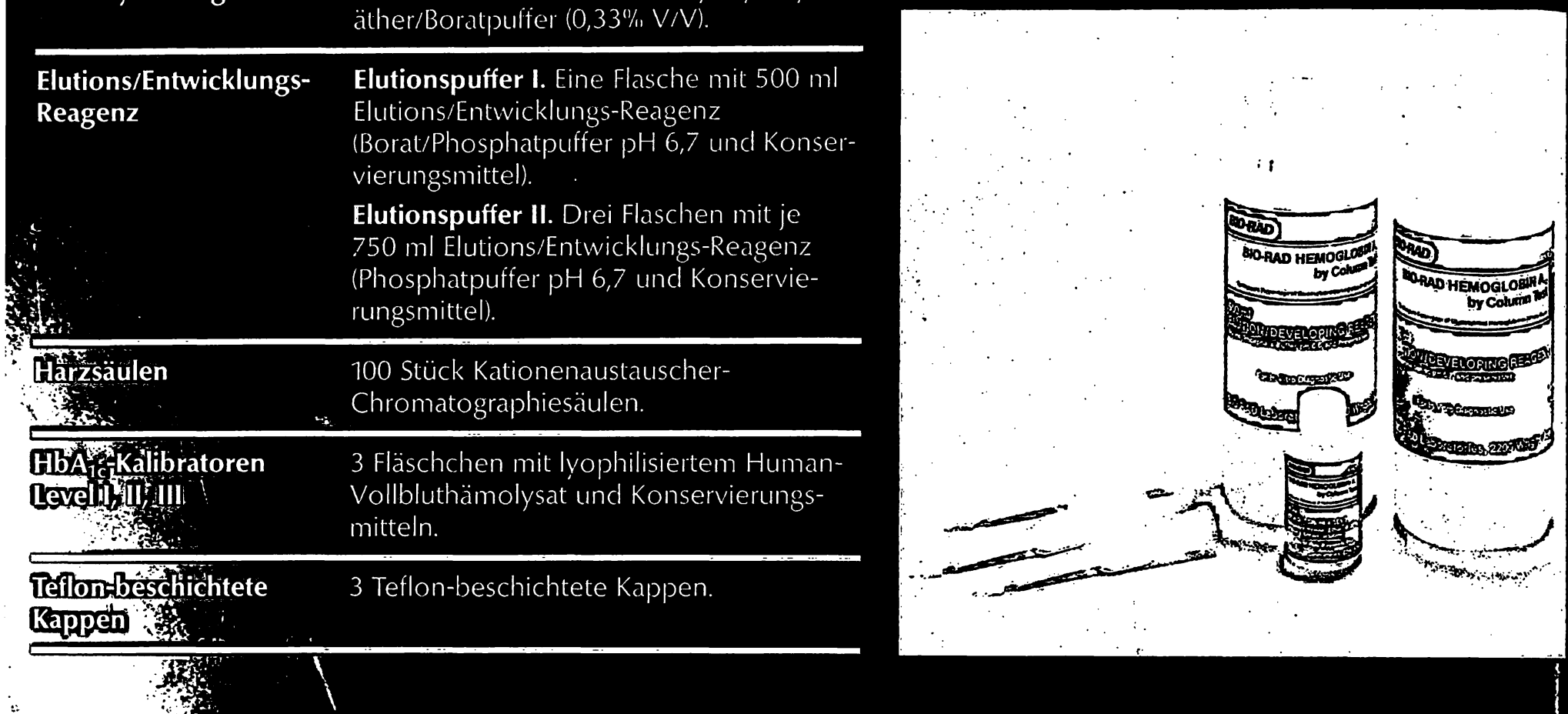

\section{BIORAD}

Bio-Rad

Laboratories $\mathrm{GmbH}$

Dachauer Straße 364 Postfach 50-0167 8000 München 50 Telefon 089-1411011 Telex 05-29514
Österreich

Bio-Rad Laboratories Ges.mbH - Auhofstralse 78D - A-1130 Wien - Telefon (()222) 859194) Telex 136565 Schweiz

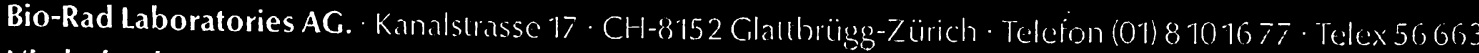
Niederlande

Bio-Rad Laboratories B.V. C Ceylonlaan 6. 3526 AD Utrecht - Tcleion (030) 88\%14\% - Telex 70)42 